\title{
The problem of development of interpersonal relations in the primary school age Tolstaia S. ${ }^{1}$, Rosca M. ${ }^{2}$ (Republic of Moldova) Проблема развития межличностных отношений в младшем школьном возрасте Толстая С. В. ${ }^{1}$, Рошка М. ${ }^{2}$ (Республика Молдова)
}

\author{
${ }^{I}$ Толстая Светлана Викторовна / Tolstaia Svetlana - доктор психологии, доиент, \\ кафедра психологии; \\ ${ }^{2}$ Pошка Мария / Rosca Maria - докторант, \\ докторальная школа психологии и педагогических наук, Молдавский государственный университет, г. Кишинёв
}

\begin{abstract}
Аннотация: в статье рассматриваются проблемы межличностных отношений младших школьников, представлены их особенности, функиии, уровни проявления и возможные трудности.

Abstract: this article examines the problems of interpersonal relations of younger schoolchildren, presented their particular qualities, functions, levels of expression and possible difficulties.
\end{abstract}

Ключевые слова: межличностные отношения, младиий школьник.

Keywords: interpersonal relations, primary school age.

Опыт межличностных отношений с другими людьми, взрослыми или сверстниками, является фундаментом для развития личности ребенка, становления его самосознания. Насколько легко ребенок будет уметь общаться с окружающими его людьми, налаживать контакт, зависит его дальнейшая учебная, рабочая деятельность, его судьба и место в жизни. Особенно актуально изучение особенностей межличностных отношений в младшем школьном возрасте, поскольку именно в этот период происходит формирование личности и возникает необходимость более глубокого психолого-педагогического изучения ребенка и его многообразных контактов со взрослыми и сверстниками.

Младший школьный возраст - это особый период в жизни ребёнка, который в возрастной психологии выделился сравнительно недавно. Он наиболее глубоко и содержательно представлен в работах Д. Б. Эльконина, В. В. Давыдова, их сотрудников и последователей (Л. И. Айдаровой, А. К. Дусавицкого, А. К. Марковой, Ю. А. Полуянова, В. В. Репина, В. В. Рубцова, Г. А. Цукерман и др.).

Итак, младший школьный возраст - это возраст 6 (7)-10-летних детей, обучающихся в 1-4 классах современной начальной школы. С приходом ребёнка в школу, как писал Д. Б. Эльконин [6; с. 88], происходит перестройка всей системы отношений ребёнка с действительностью.

В возрасте 6 лет существует своего рода напряжение и волнение, порожденные первоначальным контактом со школой, усилиями, чтобы адаптироваться к новой среде. Если адаптация к школе проходит благополучно, после 7 лет ребенок вступает в период относительного спокойствия, адаптация к переменам проходит весьма удовлетворительно, и ребенок, скорее, внутренне переживает все виды ежедневных событий. Эта внутренняя тревожность провоцирует любопытство ребенка, что благоприятно сказывается на расширении отношений с окружающим миром. К 9 годам появляются очевидные новые возможности самосознания и автономии, и поэтому ребенок становится более упорядоченным, более серьезным и даже чувствует потребность организовать свое время. К 10 годам ребенок достигает своего рода кульминации детства, проявляющееся в умении быстро ориентироваться в школьной жизни, решать школьные проблемы, умении понимать разные ситуации, спокойствии, умении владеть собой и сдерживать эмоциональные реакции $[1,6]$.

Приобретение навыков социального взаимодействия с группой сверстников и умение заводить друзей являются одной из важнейших задач развития ребенка на этом возрастном этапе [1]. В период младшего школьного возраста идет формирование новых типов отношений, основанных на том, что школа как социальный институт состоит из классов - коллективов детей равных по возрасту и проходящих одинаковое обучение, что порождает сильный конкурентный дух [2].

В школе, согласно Д. Б. Эльконину [6; с. 94], возникает новая структура этих отношений. Система «ребёнок - взрослый» дифференцируется на: ребенок - учитель и ребенок - родители. Наиболее важной для развития самосознания ребенка считается система «ребёнок - учитель». Учитель не только обучает детей различным предметам и открывает им много интересного об окружающем мире, но и оказывает влияние на формирование представления ребенка о себе, своих способностях, а также определяет отношение ребёнка к родителям и отношение к детям. Система «ребёнок - учитель» становится центром жизни ребёнка, от неё зависит совокупность всех благоприятных для жизни условий.

Важно отметить, что на процесс развития межличностных отношений наибольшее влияние оказывает воспитательное воздействие учителя, которое может также функционировать в качестве критерия анализа взаимодействий в классе:

- отношения сотрудничества: на основе координации усилий с целью достижения общей цели,

• отношения конкуренции: соперничество в достижении индивидуальных целей, 
• конфликтные отношения: отношения оппозиции в достижении индивидуальных целей.

Мортон отметил, что в классах с конкурентной атмосферой дети имеют высокий уровень тревожности, дети меньше думают о себе и своих делах, с предубеждением относятся к одноклассникам и проявляют низкий уровень ответственности. Deutsch изучал явления соперничества и сотрудничества в коллективах детей в течение 35 лет назад, что привело к важному для учителей выводу: чем больше детей участвуют в деятельности, которая требует сотрудничества, тем общая атмосфера в классе будет лучше. Развитие различных интересов в специализированной роли кооперативной системы, повышение фаворитизма может привести к дискриминации в отношении членов коллектива, которые не являются частью группы, и к росту чрезмерного конформизма при отсутствии мнения большинства [7].

Воспитательное воздействие можно определить как организационную и структурированную форму образовательного процесса, направленную на ученика с целью формирования и развития его поведения, отношений и т. д. В данном случае воспитательное воздействие можно анализировать с двух позиций:

- внешний фактор: личное влияние учителя как лидера;

- внутренний фактор: влияние группы, регулирующей формальные и неформальные процессы внутри класса.

Личное влияние учителя определяется как способность влиять на поведение других людей в каждый момент взаимодействия учитель - ученик. Успешность воспитательного воздействия учителя зависит от четырех факторов: особенности эмоциональных отношений, установленных между учителем и учениками; восприятие учителя учениками; степень использования учителем власти; степень индивидуализации стратегий работы, используемых учителем [4].

Класс, как школьная форма социальной организации детей, оказывает все возрастающее влияние на развитие ребенка, помогая в усвоении новых правил, социальных норм, ценностных ориентаций. В коллективе класса ребенок развивает навыки общения, получает опыт коллективной деятельности, развивает самооценку и получает возможность личного самоутверждения. Однако следует отметить, что создание и сплочение коллектива класса - это одна из первостепенных задач учителя.

Общение со сверстниками играет важную роль в этом возрасте, так как не только помогает социализации детей в новых условиях, стимулирует их учебу, но и способствует формированию адекватной самооценки.

Самооценка и самопознание младших школьников формируется в процессе общения со сверстникам, ребенок воспринимает себя через призму коллектива как составную часть сообщества. Оценка детьми своих сверстников связана с уровнем развития оптимизма, доброты, искренности, рефлексии собственного поведения. Дети, демонстрирующие менее адекватное поведение и проявляющие нетерпение, злость, обидчивость, как правило, более тяжело устанавливают межличностные отношения, менее общительны. Взрослые, участвующие в воспитательно-образовательном процессе, являются единственным фактором, способным помочь таким деткам установить и наладить отношения с коллективом в классе. Дети первых - вторых классов не обладают еще достаточно развитыми моральнонравственными суждениями, не могут самостоятельно дать оценку той или иной форме поведения и чаще всего ориентируются на мнение взрослых. Для детей этого возраста личность учителя является моделью для подражания, именно поэтому учителю необходимо выступить в роли инициаторов общения и поддержать межличностное взаимодействие детей. Именно в младших классах закладываются основы независимого мышления и личной автономии, умение формировать и отстаивать свою точку зрения, делать выборы. Однако такое формирование личности возможно только в коллективе, где учитель моделирует и поддерживает должное поведение.

Характер маленького ребенка развивается благодаря тому, что сама социальная ситуация (школа и класс) ежедневно моделирует новые ситуации, помещает ребенка в новые обстоятельства и дает ему возможность видеть, участвовать и анализировать различные случаи, формы поведения и т. д. Жизнь в коллективе помогают ребенку развивать моральное поведение и такие чувства, как ответственность, честность, бескорыстие, искренность, взаимопомощь, солидарность. Отсюда мы приходим к выводу, что именно учебно-воспитательный процесс формируют основу характера и личности.

Дети по-разному относятся к своим товарищам: одних одноклассников ученик выбирает, других не выбирает, третьих отвергает; отношение к одним устойчиво, к другим неустойчиво [3]. У детей младшего школьного возраста зачастую возникает интерес к друзьям тогда, когда они хотят поделиться своими идеями, интересами, когда им грустно, или они не решаются что-то сделать, когда они открыли для себя нечто новое и чувствуют потребность в общении, когда они нуждаются в эмоциональном комфорте, и друг одного и того же с ним возраста является бесценным сокровищем. Подобного рода отношение к сверстнику-другу возможно, потому что в данном возрасте дети живут с осознанием того, что «Я» имеет те же характеристики, что и «Ты» (другой). Друг для ребенка становится объектом солидарности, доверия и теплого эмоционального отношения. Однако не стоит забывать и роль семьи. Именно доброжелательная семейная обстановка, любовь родителей способствует положительному позиционированию ребенка в школе и формированию адекватной самооценки и соответствующего 
самосознания. Во всех типах межличностного взаимодействия (с родителями, в семье, с учителями, с одноклассниками, со сверстниками и т. д.) дети учатся и развивают свою способность к самонаблюдению, самоанализу и самооценки.

В младшем школьном возрасте отношения только с одним другом встречаются достаточно редко. Чаще всего дети строят дружеские отношения с коллегами, которые хорошо учатся, которые представляют модель поведения, потому что их выделяет и хвалит учитель. Дети устанавливают отношения дружбы и научают общаться так, как делают взрослые, родственники, сверстники и, конечно, учитель. У младших школьников много друзей и среди классного коллектива, и во дворе, и в кружках, и в секциях, которые они посещают. Однако им важно, чтобы эти отношения поддерживались взрослыми, участвующими в воспитании детей. В этой связи следует обратить внимание на то, что в борьбе за похвалу учителя, дети борются со своими сверстниками, поскольку видят друг в друге соперников. Для взросления личности младшего школьника важно научиться воспринимать сверстников как коллег.

Отметим еще одну особенность межличностных отношений младших школьников: отношения строятся по половому признаку, более того, группы мальчиков и девочек в этом возрасте могут даже враждовать между собой. Разделение по половому признаку в этом возрасте характеризует не только составы групп, но и места проведения игр и развлечений. При этом на всей территории игр образуются специальные «девчоночьи» и «мальчишечьи» места, внешне никак не обозначенные, но оберегаемые от вторжения «посторонних» и избегаемые ими. Интересно, что в случае объединения мальчиков и девочек для общей игры для нее выбирается место между двумя территориями [5].

Итак, отношения с другими людьми зарождаются и наиболее интенсивно развиваются в детском возрасте. Опыт этих первых отношений является фундаментом для дальнейшего развития личности ребенка и во многом определяет особенности его отношения к себе, к другим, к миру в целом. Таким образом, можно сделать вывод о том, что межличностные отношения в младшем школьном возрасте зависят от многих факторов, таких как успешность в учебе, взаимная симпатия, общность интересов, внешние жизненные обстоятельства, половые признаки. Эти все факторы влияют на характер взаимоотношений ребенка с окружающими людьми и их значимость.

\section{Литература}

1. Выготский Л. С. Педагогическая психология / Под ред. В. В. Давыдова. М.: 1999. 560 с.

2. Матюхина М. В. Психология младшего школьника. Учеб. пособ. для студ. заочников факультетов подготовки учителей начальных классов. - изд. 2-е, испр. и доп. М.: Просвещение, 1976. 207 с.

3. Сапогова E. Е. Психология развития человека: учебное пособие. М.: Аспект пресс, 2001.460 с.

4. Толстая C. Условия совершенствования и профессионального саморазвития педагогов // Международная научная конференция «Învățământul universitar i pia a muncii: conexiuni i perspective», 21 noiembrie, 2014, USM. c. 460-469.

5. Фернхем А., Хейвен П. Личность и социальное поведение. СПб.: Питер, 2001. 368 с.

6. Эльконин Д. Б. Детская психология. Москва: Аспект пресс, 2006. 380 с.

7. Bolboceanu A. Impactul comunicării cu adultul asupra dezvoltării intelectuale în diferite perioade ale ontogenezei. Teză de dr. hab. în psihologie. Chişinău, 2005. 259 p. 